\title{
CONTRAST SENSITIVITY IN DEEP ANTERIOR LAMELLAR KERATOPLASTY VERSUS PENETRATING KERATOPLASTY
}

Carlos Anchieta Castro Cardoso da Silva, Ederson Schweitzer de Oliveira, Manoel Paulo Souza de Sena Júnior, Luciene Barbosa de Sousa

Cardoso da Silva CAC, de Oliveira ES, de Sena Júnior MPS, de Sousa LB.Contrast Sensitivity in Deep Anterior Lamellar Keratoplasty versus Penetrating Keratoplasty. Clinics. 2007;62(6):705-8.

PURPOSE: To compare the measurements of contrast sensitivity at a distance in patients submitted to penetrating keratoplasty versus patients submitted to deep anterior lamellar keratoplasty for keratoconus treatment.

METHODS: Contrast sensitivity of 15 subjects submitted to penetrating keratoplasty and 15 subjects submitted to deep anterior lamellar keratoplasty have been analyzed through the Functional Acuity Contrast Test (F.A.C.T®) 301.

RESULTS: There was no statistically significant difference between the measurements for penetrating keratoplasty and deep anterior lamellar keratoplasty.

CONCLUSION: Contrast sensitivity was similar among the subjects submitted to penetrating keratoplasty and to deep anterior lamellar keratoplasty for keratoconus treatment.

KEYWORDS: Cornea. Corneal transplantation. Corneal diseases. Keratoconus. Contrast sensitivity

\section{INTRODUCTION}

The keratoconus is a bilateral corneal disease that attacks 1 out of 2,000 people throughout the world ${ }^{1}$. It typically appears in late adolescents and young adults whose mean age is 22.4 years old. ${ }^{2}$ It is a progressive disease ${ }^{3}$ and the main cause of keratoplasty in young adults. ${ }^{4-5}$

Recent advances in surgical techniques have encouraged an exchange of treatment methods for corneal disease surgery. Many types of lamellate techniques are replacing the technique of penetrating keratoplasty. This is primarily because lamellate techniques keep the healthy tissue uncut and replace the modified tissue. ${ }^{6}$

Deep anterior lamellar keratoplasty is a safe method to treat keratoconus surgically. It is also similar to the penetrating keratoplasty method in terms of the visual acuity

Hospital Oftalmológico de Sorocaba - Banco de Olhos de Sorocaba

Email: carlosanchieta@oi.com.br

Received for publication on June 08, 2007

Accepted for publication on August 22, 2007 results and the lack of risk of endothelial rejection. ${ }^{7-9}$

Snellen visual acuity is used for a long time as a successful method of checking the result of surgeries. However, during the last two decades studies have shown that there are different aspects of visual function, not solely the acuity aspect, which is compromised in patients who suffer from vision opacity and corneal irregularity. ${ }^{10-13}$ Another of those aspects consists of contrast sensitivity, which has been widely accepted as a visual quality indicator. ${ }^{14}$

This study used the contrast sensitivity method to identify and analyze differences in quality of visual function for patients who had either undergone penetrating keratoplasty or deep anterior lamellar keratoplasty surgery to treat keratoconus.

\section{METHODS}

Subjects for this study voluntarily agreed to participate after the purpose of the research had been explained to them.

Inclusion criteria were as follows: a best-case spectaclecorrected visual acuity of $\geq 20 / 30$ in patients over 14 years 
old who had undergone keratoplasty and had no post-operative complications for at least 12 months.

The keratoconus diagnosis was based on refraction and the computerized topography of the cornea.

Exclusion criteria were as follows: a best-case spectacle-corrected visual acuity $<20 / 30$, other previous ocular surgery, or complications during or after surgery.

The patients were split into two groups:

Group I - Patients submitted to penetrating keratoplasty,

Group II - Patients submitted to deep anterior lamellar keratoplasty.

The corneas were kept and well-preserved in Optisol®.

The deep anterior lamellar keratoplasties were carried out through a deep dissection technique with air. The Descemet membrane and the corneal endothelium were kept intact.

Snellen visual acuity (VA) and the contrast sensitivity (CS) were measured in one eye of each of 15 patients in each group.

The Functional Acuity Contrast Test (F.A.C.T.® 301, Stereo Optical, Chicago, IL) was used to perform the contrast sensitivity test. The distance was set at 10 feet $(3.05$ m) and the light between 68 and $240 \mathrm{~cd} / \mathrm{m}^{2}$. The test was performed with spectacle correction. The test, which is based on a table with grades, measures the contrast sensitivity of five different spatial frequencies: $1.5 \mathrm{cpd}$ (cycles per degree), $3.0 \mathrm{cpd}, 6.0 \mathrm{cpd}, 12.0 \mathrm{cpd}$ and $18 \mathrm{cpd}$. The results can be evaluated by the Snellen Functional Acuity Equivalent or assessed separately in each spatial frequency.

The measures of each spatial frequency and the Snellen Functional Equivalent values were compared between the two groups. The Student's $t$ test was used to verify if the mean values of the groups were different. The level of significance was $5 \%$ for the statistical analysis $(\mathrm{p}<0.05)$.

Demographic data were also considered.

\section{RESULTS}

The age of the patients in Group I (penetrating keratoplasty) varied between 14 and 34 years old, with a mean of $25.5 \pm 6.64$. Group II (deep anterior lamellar keratoplasty) patients' ages varied between 14 and 49; the mean age was $28.3 \pm 13.2$ (Table 1$)$.

Group I had eight (53.3\%) female patients and seven

Table 1 - Patients' profile.

\begin{tabular}{lcc}
\hline & Group I & Group II \\
\hline Mean age $(y)$ & $25.5( \pm 6.64)$ & $28.3( \pm 13.2)$ \\
Gender & $53.3 \%$ female & $46.7 \%$ male \\
& $46.7 \%$ male & $53.3 \%$ female \\
\hline
\end{tabular}

(46.7\%) male patients. Group II had eight (53.3\%) male patients and seven (46.7\%) female patients (Table 1).

All patients were accounted for at 12- and 24-month follow-ups.

The best spectacle-corrected visual acuity in Group I was $20 / 30$ in seven (46.7\%) patients, 20/25 in seven (46.7\%) patients and 20/20 in one (6.6\%) patient; For Group II, this distribution was 20/30 in eight (53.5\%) patients and 20/25 in seven $(46.5 \%)$ patients. The mean values of visual acuity were $0.74( \pm 0.09)$ for Group I and $0.72( \pm 0.07)$ for Group II $(\mathrm{p}=0.48)$ (Table 2).

Table 2 - Best Spectacle-Corrected Visual Acuity

\begin{tabular}{lcc}
\hline VA & Group I & Group II \\
\hline $20 / 30$ & 7 patients $(46.7 \%)$ & 8 patients $(53.5 \%)$ \\
$20 / 25$ & 7 patients $(46.7 \%)$ & 7 patients $(46.5 \%)$ \\
$20 / 20$ & 1 patient $(6.6 \%)$ & - \\
\hline VA &
\end{tabular}

$\mathrm{VA}=$ visual acuity.

Table 3 shows the refraction values and visual acuity with spectacle correction in each case.

Table 3 - Refraction and Visual Acuity

\begin{tabular}{lccccc}
\hline & GROUP I & & & \multicolumn{2}{c}{ GROUP II } \\
Patient & Refraction & VA & Patient & Refraction & VA \\
\hline $\mathbf{1}$ & $+2.00-3.0040^{\circ}$ & $20 / 30$ & $\mathbf{1 6}$ & $+3.00-3.0015^{\circ}$ & $20 / 30$ \\
$\mathbf{2}$ & $-3.50-3.00180^{\circ}$ & $20 / 30$ & $\mathbf{1 7}$ & $-0.50-3.50120^{\circ}$ & $20 / 25$ \\
$\mathbf{3}$ & $-2.25-3.7590^{\circ}$ & $20 / 30$ & $\mathbf{1 8}$ & $-2.00-3.0085^{\circ}$ & $20 / 30$ \\
$\mathbf{4}$ & $-1.00-1.7555^{\circ}$ & $20 / 25$ & $\mathbf{1 9}$ & $-6.00-3.5085^{\circ}$ & $20 / 30$ \\
$\mathbf{5}$ & $+2.00-3.0060^{\circ}$ & $20 / 30$ & $\mathbf{2 0}$ & $-0.50-2.00150^{\circ}$ & $20 / 25$ \\
$\mathbf{6}$ & $-2.0030^{\circ}$ & $20 / 25$ & $\mathbf{2 1}$ & $-5.00-2.0025^{\circ}$ & $20 / 30$ \\
$\mathbf{7}$ & $-1.50-3.5090^{\circ}$ & $20 / 30$ & $\mathbf{2 2}$ & +3.00 & $20 / 30$ \\
$\mathbf{8}$ & $-3.00-2.0020^{\circ}$ & $20 / 25$ & $\mathbf{2 3}$ & $+0.50-3.0040^{\circ}$ & $20 / 30$ \\
$\mathbf{9}$ & $-2.00-2.0035^{\circ}$ & $20 / 25$ & $\mathbf{2 4}$ & $-0.50-2.0010^{\circ}$ & $20 / 25$ \\
$\mathbf{1 0}$ & $-0.50-3.00185^{\circ}$ & $20 / 30$ & $\mathbf{2 5}$ & $-2.505^{\circ}$ & $20 / 25$ \\
$\mathbf{1 1}$ & $-0.50-2.00170^{\circ}$ & $20 / 25$ & $\mathbf{2 6}$ & $-2.50-1.5075^{\circ}$ & $20 / 30$ \\
$\mathbf{1 2}$ & $-1.00-1.5010^{\circ}$ & $20 / 25$ & $\mathbf{2 7}$ & $-1.00-1.0035^{\circ}$ & $20 / 25$ \\
$\mathbf{1 3}$ & $-1.00-2.0080^{\circ}$ & $20 / 25$ & $\mathbf{2 8}$ & $-2.00-1.00180^{\circ}$ & $20 / 25$ \\
$\mathbf{1 4}$ & $-2.00-1.0030^{\circ}$ & $20 / 20$ & $\mathbf{2 9}$ & $-1.00-1.5060^{\circ}$ & $20 / 25$ \\
$\mathbf{1 5}$ & $-6.00-2.2560^{\circ}$ & $20 / 30$ & $\mathbf{3 0}$ & $-0.50-2.5030^{\circ}$ & $20 / 30$ \\
\hline
\end{tabular}

VA: Visual Acuity.

There was no statistically significant difference in contrast sensitivity in any spatial frequency evaluated between the groups. The mean value and the standard deviation presented for all frequencies were. (Table 4 and Figure 1).

For to the Snellen Functional Acuity Equivalent, Group I showed a mean value of $0.317( \pm 0.177)$ and Group II, 0.290 ( $\pm 0.133 ; p=0.644)$. There was no statistically significant difference (Table 5). 
Table 4 - Comparison of the results in each spatial frequency.

\begin{tabular}{lccccc}
\hline \multirow{2}{*}{$\begin{array}{l}\text { Spacial } \\
\text { frequency }\end{array}$} & \multicolumn{2}{c}{ Group I } & \multicolumn{2}{c}{ Group II } & \\
& $\begin{array}{c}\text { Mean } \\
\text { Score }\end{array}$ & $\begin{array}{c}\text { Standard } \\
\text { Deviation }\end{array}$ & $\begin{array}{c}\text { Mean } \\
\text { Score }\end{array}$ & $\begin{array}{c}\text { Standard } \\
\text { Deviation }\end{array}$ & Significance \\
\hline $1.5 \mathrm{cpd}^{*}$ & 6.0 & \pm 1.15 & 6.2 & \pm 0.79 & $\mathrm{p}=0.65$ \\
$3 \mathrm{cpd}$ & 4.2 & \pm 1.55 & 4.2 & \pm 1.55 & $\mathrm{p}=0.40$ \\
$6 \mathrm{cpd}$ & 3.1 & \pm 1.79 & 3.1 & \pm 2.23 & $\mathrm{p}=1.00$ \\
$12 \mathrm{cpd}$ & 1.9 & \pm 1.37 & 1.2 & \pm 0.42 & $\mathrm{p}=0.14$ \\
$18 \mathrm{cpd}$ & 1.6 & \pm 1.07 & 1.1 & \pm 0.31 & $\mathrm{p}=0.19$ \\
\hline
\end{tabular}

$*$ cpd $=$ cycles per degree

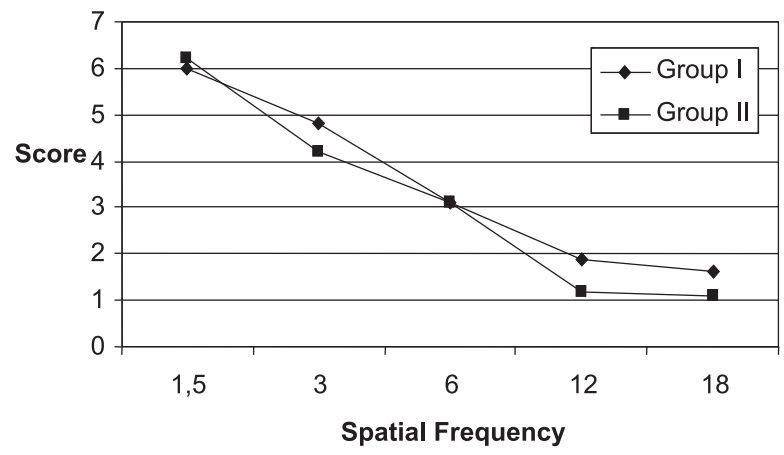

Figure 1 - Results of contrast sensitivity.

Table 5 - Comparison of Snellen Functional Acuity Equivalent (decimal value).

\begin{tabular}{ccccc}
\hline \multicolumn{2}{c}{ Group I } & \multicolumn{2}{c}{ Group II } & \\
Mean & $\begin{array}{c}\text { Standard } \\
\text { Deviation }\end{array}$ & Mean & $\begin{array}{c}\text { Standard } \\
\text { Deviation }\end{array}$ & Significance \\
\hline 0.31 & \pm 0.17 & 0.29 & \pm 0.13 & $\mathrm{p}=0.64$ \\
\hline
\end{tabular}

(Significance: $\mathrm{p}<0.05$ ).

\section{DISCUSSION}

Many studies have reached the conclusion that deep anterior lamellar keratoplasty yields great visual results in treating keratoconus; further, it risks neither endothelial failure nor endothelial rejection. ${ }^{7-9,15}$

Others have concluded that the best spectacle-corrected visual acuity results are similar between penetrating keratoplasty and deep anterior lamellar keratoplasty. ${ }^{8,17}$

Studies have shown how useful the contrast sensitivity test is in assessing the progress of keratoconus, while also providing a successful evaluation method for keratoplasty. ${ }^{16,19}$

Recent studies have revealed no differences related to contrast sensitivity at a distance when comparing penetrating keratoplasty patients against deep anterior lamellar keratoplasty patients. Results have also shown that visual acuity after deep anterior lamellar keratoplasty is dependent on the thickness of the residual recipient stromal bed, with a better visual acuity in cases with less residual stromal thickness. ${ }^{19}$

This study has shown that further contrast sensitivity had similar statistical values in all spatial frequencies evaluated $(1.5 \mathrm{cpd} ; 3.0 \mathrm{cpd} ; 6.0 \mathrm{cpd} ; 12.0 \mathrm{cpd}$ and $18.0 \mathrm{cpd})$ between Groups I and II.

\section{CONCLUSION}

For tests of contrast sensitivity at a distance in one-yearpost-operative surgery patients, the deep anterior lamellar keratoplasty procedure has shown similar results to the penetrating keratoplasty procedure for treatment of keratoconus.

\section{RESUMO}

Cardoso da Silva CAC, de Oliveira ES, de Sena Júnior MPS, de Sousa LB. Sensibilidade ao Contraste entre Transplante Lamelar Anterior Profundo e Transplante Penetrante de Córnea. Clinics. 2007;62(6):705-8.

OBJETIVO: Comparar as medidas de sensibilidade ao contraste à distância entre pacientes submetidos à ceratoplastia penetrante e pacientes submetidos à ceratoplastia lamelar anterior profunda para tratamento do ceratocone.

MÉTODOS: Sensibilidades ao contraste de 15 pacientes submetidos à ceratoplastia penetrante e de 15 pacientes submetidos à ceratoplastia lamelar anterior profunda foram analisadas através do Functional Acuity Contrast Test (F.A.C.T®) 301.

RESULTADOS: Não existiu diferença estatisticamente significante entre as medidas em ceratoplastia penetrante e ceratoplastia lamelar anterior profunda.

CONCLUSÃO: Sensibilidade ao contraste foi similar entre os pacientes submetidos à ceratoplastia penetrante e à ceratoplastia lamelar anterior profunda para tratamento do ceratocone.

UNITERMOS: Córnea. Transplante de córnea. Doenças da córnea. Ceratocone. Sensibilidade de contraste. 


\section{REFERENCES}

1. Rabinowitz YS. Keratoconus. Surv Ophthalmol.1998;42:297-319.

2. Tuft SJ, Moodaley LC, Gregory WM, Davison CR, Buckey RJ. Prognostic factors for the progression of keratoconus. Ophthalmology. 1994; 01:439-447.

3. Krachmer JH, Feder RS, Belin MW. Keratoconus and related noninflammatory corneal thinning disorders. Surv Ophthalmol. 1984; 28:293-322.

4. Calix Netto MJ, Giustina ED, Ramos GZ, Peccini RF, Sobrinho M, de Souza LB. Major indications for corneal penetrating keratoplasty at a reference service in Sao Paulo state (Sorocaba - SP, Brazil). Arq Bras Oftalmol. 2006;69:661-664.

5. Vail A, Gore SM, Bradley BA, et al. On behalf of Corneal Transplant Follow-up Study Collaborators. Corneal graft survival and visual outcome: a multicentre trial. Ophthalmology. 1993;101:120-127.

6. Shimmura S, Tsubota K. Deep anterior lamellar keratoplasty. Curr Opin Ophthalmol. 2006;17:349-355.

7. Watson SL, Ramsay A, Dart JK, Bunce C, Craig E. Comparison of deep lamellar keratoplasty and penetrating keratoplasty in patients with keratoconus. Ophthalmology. 2004;111:1676-682.

8. Vabres B, Bosnjakowski M, Bekr L, Weber M, Pechereau A. Deep lamellar keratoplasty versus penetrating keratoplasty for keratoconus. J Fr Ophtalmol. 2006;29:361-371.

9. Funnell CL, Ball J, Noble BA. Comparative cohort study of the outcomes of deep lamellar keratoplasty and penetrating keratoplasty for keratoconus. Eye. 2006;20:527-532.

10. Rubin GS, Adamsons IA, Stark WJ. Comparison of acuity, contrast sensitivity, and disability glare before and after cataract surgery. Arch Ophthalmol. 1993;111:56-61.
11. Bodis-Wollner I. Detection of visual defects using the contrast sensitivity function. Int Ophthalmol Clin. 1980;20:135-153.

12. Elliot DB, Hurst MA, Weatherill J. Comparing clinical tests of visual function in cataract with the patient's perceived visual disability. Eye. 1990; 4:712-717.

13. Mannis MJ, Zadnik K, Johnson CA. The effect of penetrating keratoplasty on contrast sensitivity in keratoconus. Arch Ophthalmol. 1984; 102:1513-1516.

14. McLeod SD. Beyond Snellen acuity: the assessment of visual function after refractive surgery. Arch Ophthalmol. 2001;119:1371-1373.

15. Fournie P, Coullet J, Moalic S, Malecaze F, Chapotot E, Arne JL. Deep anterior lamellar keratoplasty in the surgical treatment of keratoconus. A 1-year follow-up. J Fr Ophtalmol. 2006;29:602-613.

16. Pesudovs K, Schoneveld P, Seto RJ, Coster DJ. Contrast and glare testing in keratoconus and after penetrating keratoplasty. Br J Ophthalmol. 2004; 88:653-657.

17 Brahma A, Ennis F, Harper R, Ridgway A, Tullo A. Visual function after penetrating keratoplasty for keratoconus: a prospective longitudinal evaluation. Br J Ophthalmol. 2000;84:60-66.

18. Zadnik K, Mannis MJ, Johnson CA. An analysis of contrast sensitivity in identical twins with keratoconus. Cornea. 1984;3:99-103.

19. Ardjomand N, Hau S, McAlister JC, Bunce C, Galaretta D, Tuft SJ, Larkin DF. Quality of vision and graft thickness in deep anterior lamellar and penetrating corneal allografts. Am J Ophthalmol. 2007;143:228-235. 